\title{
CONSIDERAÇÕES PRÁTICAS SOBRE O TESTE DE DEMANDA QUÍMICA DE OXIGÊNIO (DQO) APLICADO A ANÁLISE DE EFLUENTES ANAERÓBIOS
}

\section{Practical ASPECTS OF THE CHEMICAL OXYGEN DEMAND (COD) TEST APPLIED TO THE ANALYSIS OF ANAEROBIC EFFLUENTS}

\section{SÉRGIO F. DE AQUINO}

Bacharel e Licenciado em Química (UFV). Mestre em Hidráulica e Saneamento (USP-São Carlos). Ph.D. em Engenharia Química (Imperial College London). Professor Adjunto do Departamento de Química da UFOP

\section{SILVANA DE QUEIROZ SILVA}

Bacharel em Ciências Biológicas (UFSCAR). Mestre em Hidráulica e Saneamento (USP-São Carlos). Ph.D. em Microbiologia Ambiental (University of Essex). Pós-Doutoranda do Departamento de Engenharia Sanitária em Ambiental da UFMG

\section{CARLOS A. L.CHERNICHARO}

Engenheiro Civil (UFMG). Mestre em Saneamento, Meio Ambiente e Recursos Hídricos (UFMG). Ph.D. em Engenharia Ambiental (University of Newcastle Upon Tyne). Professor Adjunto do Departamento de Engenharia Sanitária e Ambiental da UFMG

Recebido: $12 / 04 / 06$

Aceito: $18 / 07 / 06$

\section{RESUMO}

Este artigo apresenta resultados de testes laboratoriais que investigaram a influência dos íons cloreto, amonium, ferro e sulfeto no teste de demanda química de oxigênio (DQO), bem como valores dos coeficientes de conversão da matéria orgânica específica (proteínas, carboidratos e lipídeos) determinados empiricamente. $\mathrm{O}$ artigo apresenta, ainda, resultados da comparação dos métodos colorimétrico e titulométrico de determinação da DQO e faz uma discussão crítica do uso do teste de DQO como parâmetro de monitoramento da eficiência de sistemas de tratamento anaeróbio.

PALAVRAS-CHAVE: Demanda Química de Oxigênio (DQO), tatamento de águas residuárias, sulfeto, ions amônia, cloreto, ferro.

\section{INTRODUÇÃO}

A demanda química de oxigênio (DQO) é um parâmetro global utilizado como indicador do conteúdo orgânico de águas residuárias e superficiais, e bastante utilizado no monitoramento de estaçōes de tratamento de efluentes líquidos. Embora a resolução CONAMA 357/05 não faça referência ao parâmetro DQO na classificação dos corpos d'água e nos padrôes de lançamento de efluentes líquidos, algumas legislações ambientais estaduais estabelecem limites máximos para este parâmetro em seus padróes de lançamento.

\section{ABSTRACT}

This paper presents practical results on the influence of chloride, amonium, sulphide and iron on the chemical oxygen demand (COD) test, as well as experimental values of stoichiometric coefficients to convert the specific organic matter (protein, carbohydrate and lipid) into COD. The paper also presents results that compare the titrimetric and colorimetric methods used to measure the $C O D$ and makes a critical analysis of the use of COD test as a tool to monitor the efficiency of anaerobic treatment systems.

KEYWORDS: Chemical Oxygen Demand (COD), wastewater treatment, anaerobic treatment, sulphide, amonium, chloride, iron.
A DQO de amostras de águas residuárias pode ser determinada pelos métodos titulométrico e colorimétrico. A principal vantagem do método titulométrico é a possibilidade de sua utilização em amostras de elevada turbidez e cor residuais após a digestão com dicromato. Suas desvantagens incluem o consumo e preparo de agente titulante e indicador, o uso de vidraria adicional (erlemeyers e aparato de titulação), e a potencial relativização do ponto final da titulação, ou seja, cada analista pode ter uma percepção diferente do ponto de mudança de cor que determina o término da titulação com o sulfato ferroso amoniacal (FAS).
Por sua vez, a grande restrição ao método colorimétrico reside no fato de ele só poder ser usado em amostras que não exibem turbidez ou cor (principalmente com absorção máxima em torno de $600 \mathrm{~nm}$ ) persistentes após a digestão da amostra. Vale ressaltar que no procedimento colorimétrico é essencial que a cubeta ou tubo de vidro utilizados para leitura da absorção não estejam avariados, e que os recipientes utilizados na leitura das amostras sejam os mesmos utilizados para a construção da curva de calibração. Desta forma, é desaconselhável a utilização do próprio tubo de reação para a leitura da absorção em aparelhos do tipo DR2000, devendo-se, 
nesses casos, transferir as amostras digeridas do tubo de reação para um tubo de leitura isento de ranhuras e de uso exclusivo no espectrofotômetro.

A DQO mede, indiretamente, os equivalentes redutores (elementos com baixo número de oxidação, ou seja, reduzidos) presentes na amostra em questão. Dessa forma, causará DQO a amostra que contiver substâncias orgânicas e/ou inorgânicas passíveis de oxidação pelo dicromato de potássio $\left(\mathrm{K}_{2} \mathrm{Cr}_{2} \mathrm{O}_{7}\right)$ em meio ácido. Em se tratando de esgotos tipicamente domésticos, a fração orgânica, em geral, supera a fração inorgânica reduzida, e a DQO pode ser utilizada, sem maiores problemas, para quantificar diretamente a matéria orgânica oxidável presente. Entretanto, alguns efluentes industriais podem conter significativas concentrações de substâncias inorgânicas reduzidas, que podem ser oxidadas pelo dicromato e causar DQO. Além do mais, uma expressiva contribuição das substâncias inorgânicas para a DQO pode resultar em uma baixa relação $\mathrm{DBO} / \mathrm{DQO}$ e à errônea conclusão de que o tratamento biológico não é susceptível, a despeito de a fração orgânica poder ser facilmente degradável. Como exemplo, o monitoramento de um sistema de tratamento que recebe contribuição significativa de substâncias inorgânicas oxidáveis, ou que resulta na produção de substâncias reduzidas (Ex. sulfetos durante o tratamento anaeróbio) pode subestimar a capacidade do sistema na remoção de matéria orgânica afluente.

Para evitar problemas de interpretação associados ao uso do parâmetro
DQO, Vogel et al (2000) propuseram o uso do conceito do número médio de oxidação do carbono (MOC - mean oxidation number of carbon), i.e. a relação COT/DQO (carbono orgânico total dividido pela demanda química de oxigênio) para avaliar com mais precisão a remoção de matéria orgânica em sistemas de tratamento. Geralmente, uma baixa relação $\mathrm{COT} / \mathrm{DQO}$ indica baixo conteúdo de carbono e/ou baixo número médio de oxidação do carbono (MOC). Como mostra a Figura 1, a presença de heteroátomos (elementos diferentes do carbono e hidrogênio: $\mathrm{N}, \mathrm{S}, \mathrm{O}, \mathrm{P}$ ) tende a aumentar a polaridade dos compostos orgânicos e levar ao aumento do número de oxidação médio do carbono, aumentando, consequentemente, a relação COT/DQO. Como regra geral, quanto maior o número de insaturaçôes e/ou a presença de heteroátomos mais eletronegativos que o carbono, maior será o número de oxidaçāo médio do carbono, o que tenderia a abaixar o valor da DQO, resultando, consequentemente, em maior relação COT/DQO. Pode-se afirmar, ainda, que quanto menor a relação entre o número de carbono e de heteroátomos em uma molécula (C/heteroátomo), maior é a polaridade da molécula e mais hidrofílica ela deveria ser.

Se a análise da eficiência de um sistema de tratamento na remoção de matéria orgânica for feita apenas com base na DQO, deve-se ter em mente que compostos inorgânicos reduzidos, tanto na forma dissolvida quanto particulada, podem contribuir significativamente para a DQO. Kylefors et al (2003) estudaram os efeitos da presença de Fe (II), Mn (II), sulfeto, íons amônia e cloretos, além da concentração de dicromato e tempo de reação, no valor experimental da DQO de lixiviados de aterro sanitário. Os pesquisadores mostraram que aproximadamente um terço da DQO dos lixiviados estudados eram devido a substâncias inorgânicas presentes, e concluíram que a DQO não pode ser utilizada como único parâmetro de medida do conteúdo orgânico de lixiviados uma vez que substâncias inorgânicas, bem como suas interaçôes, podem interferir no resultado da DQO. Vogel et al (2000) classificaram as substâncias que interferem no teste de DQO em: completamente; parcialmente; e dificilmente oxidáveis. Segundo esses pesquisadores, os íons sulfeto, nitrito, cloreto e Fe (II) seriam completamente oxidáveis, enquanto o íon amônio seria dificilmente oxidável.

Com base no exposto, o objetivo desse artigo é apresentar resultados experimentais do efeito dos íons cloreto, amonium, ferro e sulfeto no teste de demanda química de oxigênio (DQO), e discutir suas implicações. Ademais, este artigo apresenta valores experimentais de coeficientes para conversão da matéria orgânica específica (proteínas, carboidratos e lipídeos) em DQO.

\section{MATERIAIS E MÉTODOS}

\section{Análise da DQO}

O método padrão para determinação da DQO utiliza dicromato de potássio $\left(\mathrm{K}_{2} \mathrm{Cr}_{2} \mathrm{O}_{7}\right)$ como agente oxidante. Embora haja dois métodos distintos para a quantificação do dicromato não

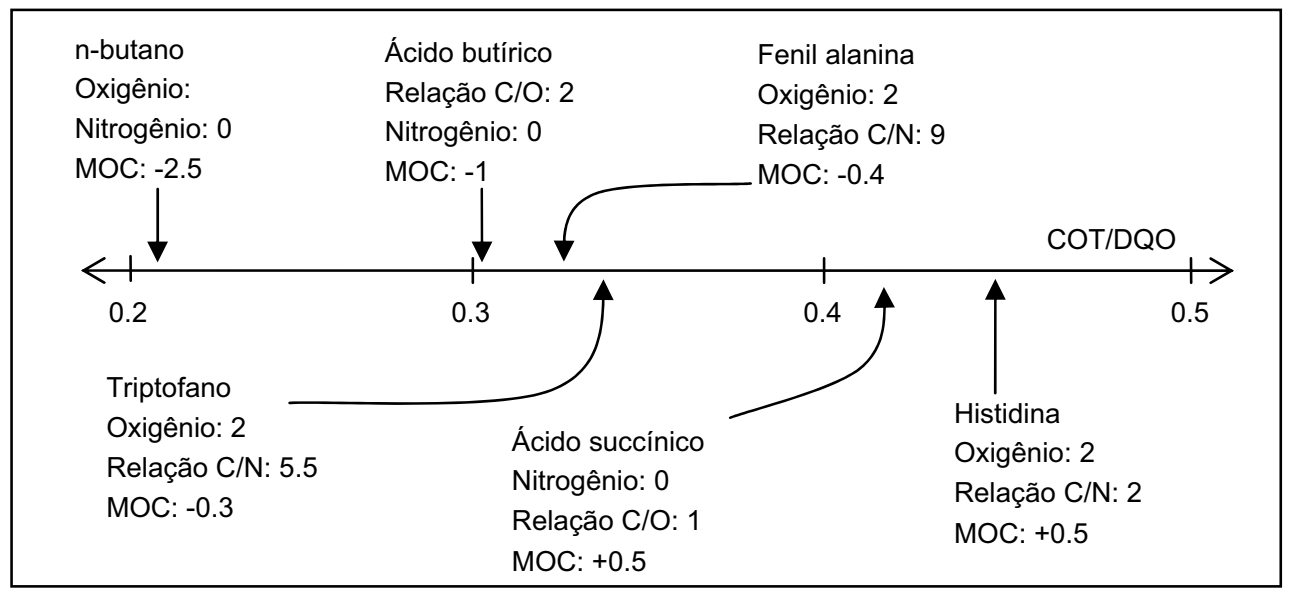

Figura I - Variação do número médio de oxidação do carbono (MOC) em função da relação COT/DQO calculada 
oxidado, a saber métodos titulométrico e colorimétrico, o procedimento de preparo e digestão das amostras é o mesmo para ambos.

Nos experimentos apresentados nesse artigo a DQO foi determinada partindo-se de $2 \mathrm{~mL}$ de amostra bruta ou diluída que foi transferida para frascos de reação (tipo Hach), aos quais foram adicionados $2 \mathrm{~mL}$ de solução de dicromato de potássio e 3,5 mL de ácido sulfúrico concentrado contendo o catalisador sulfato de prata $\left(5,5 \mathrm{gAg}_{2} \mathrm{SO}_{4} / \mathrm{kgH}_{2} \mathrm{SO}_{4}\right)$. Duas soluçōes de dicromato de potássio foram utilizadas, uma para o método titulométrico $(0,0167 \mathrm{M})$ e outra para o método colorimétrico $(0,0347 \mathrm{M})$, mas ambas continham o sulfato de mercúrio $\left(\mathrm{HgSO}_{4}\right.$ 0,1125 M ou 33,3 g/L) para minimizar a interferência causada pelos cloretos. Admitindo uma relação ideal $\mathrm{Hg}^{2+}: \mathrm{Cl}^{-}$de 10:1 (APHA, 1998), o mercúrio adicionado poderia complexar até $3.330 \mathrm{mg} / \mathrm{L}$ de cloretos, quase o dobro da concentração máxima de cloretos utilizada em alguns testes apresentados nesse artigo. Após a adição dos reagentes os tubos de reação eram tampados e levados para a digestão, por duas horas, em termoreator (Hach) mantido a $150{ }^{\circ} \mathrm{C}$. Após a digestão as amostras eram resfriadas e a quantidade de dicromato não reduzido $\left(\mathrm{Cr}_{2} \mathrm{O}_{7}^{2-}\right)$ era avaliada pelo método titulométrico, ao passo que pelo método colorimétrico avaliava-se a quantidade de cromo reduzido (Cr III), conforme descrito no Standard Methods (APHA, 1998).

No método colorimétrico a leitura da absorbância foi feita a $600 \mathrm{~nm}$, sendo as amostras transferidas do frasco de reação para um tubo de leitura de uso exclusivo no espectrofotômetro DR2010. A concentração de DQO foi calculada a partir de curva de calibração feita utilizando-se KHP - hidrogenoftalato de potássio $\left(\mathrm{C}_{8} \mathrm{H}_{5} \mathrm{O}_{4} \mathrm{~K}\right)$ como padrão. Através da equação da oxidação do KHP deduz-se que $1 \mathrm{mg} / \mathrm{L}$ de KHP exerce uma DQO teórica de $1,176 \mathrm{mgO}_{2} / \mathrm{L}$. Essa relação é então usada para preparação de diferentes soluçóes de padrão de DQO conhecida.

\section{Soluções utilizadas nos diferentes ensaios}

As seguintes soluções estoques foram utilizadas nos ensaios: $1 \mathrm{~g} / \mathrm{L}$ de caseína (solução de proteína), $20 \mathrm{~g} / \mathrm{L}$ de óleo de soja (solução de lipídeo), $2 \mathrm{~g} / \mathrm{L}$ de glicose (solução de carboidrato), $1 \mathrm{~g} / \mathrm{L}$ de hidrogênio fitalato de potássio (solução padrão de DQO), 0,2 g/L de $\mathrm{NH}_{4} \mathrm{OH}$ (solução de íons amônia), $2 \mathrm{~g} / \mathrm{L}$ de $\mathrm{NaCl}$ (solução de cloreto), $0,2 \mathrm{~g} / \mathrm{l}$ de $\mathrm{Na}_{2} \mathrm{~S} .9 \mathrm{H}_{2} \mathrm{O}$ (solução de sulfeto), $0,35 \mathrm{~g} / \mathrm{L}_{\text {de }} \mathrm{FeCl}_{2}$ (solução de ferro II), 0,35 g/L de FeSO4.7 $\mathrm{H}_{2} \mathrm{O}$ (solução de ferro III). Todas as soluções foram preparadas com reagentes de padrão analítico em água destilada e diluídas apropriadamente nos tubos de DQO para alcançar as concentraçóes desejadas.

No primeiro experimento para determinação da DQO da matéria orgânica específica, a caseína e o óleo de soja foram solubilizados por hidrólise alcalina usando-se $\mathrm{NaOH} 0,1 \mathrm{M}$, enquanto que no segundo experimento o óleo de soja foi solubilizado por hidrólise ácida usando $\mathrm{H}_{2} \mathrm{SO}_{4}(50 \%$ $\mathrm{massa} / \mathrm{massa}$ ). Como as hidrólises não resultam em mudança no número médio de oxidação do carbono, tais procedimentos não deveriam alterar a DQO dos hidrolisados.

\section{Amostras de esgoto sanitário e efluentes anaeróbios}

A comparação dos métodos titulométrico e colorimétrico empregou, além da solução padrão de KHP, amostras brutas e filtradas (por membranas com diâmetro de poro de 1,2 $\mu \mathrm{m}$ ) de esgoto sanitário e de efluente de reator UASB. As amostras foram coletadas em duas campanhas distintas em reatores anaeróbios operados em escala de demonstração na estação emperimental do DESA-UFMG junto à ETE-Arrudas (Belo Horizonte, MG).

\section{RESULTADOS E DISCUSSÃO}

\section{Comparação dos métodos titulométrico e colorimétrico}

A primeira parte desse artigo objetiva comparar resultados de DQO obtidos com os métodos colorimétrico e titulométrico, e fazer uma análise crítica em relação ao uso de ambas. Embora procedimento de digestão seja o mesmo nas duas metodologias, a concentração da solução de dicromato é diferente. Durante o método titulométrico usase uma solução de dicromato mais fraca $(0,0167 \mathrm{M})$ de forma a evitar o consumo excessivo do agente titulante. Entretanto, esse procedimento restringe a faixa de análise da DQO, uma vez que a curva de calibração é linear somente até $400 \mathrm{mg} / \mathrm{L}$ (dados não apresentados). No método colorimétrico utiliza-se uma sollução de dicromato mais concentrada $(0,0347 \mathrm{M})$ e nesse caso a curva obtida passa a ser linear até aproximadamente $1000 \mathrm{mg} / \mathrm{L}$ (dados não apresentados), o que permite o seu uso com amostras concentradas sem necessidade de diluição.

A Figura 2 (A e B) apresenta resultados da comparação do método colorimétrico e titulométrico quando aplicado à amostras do padrão KHP e percebe-se que os resultados experimentais obtidos foram bem próximos ao valor teórico. A Figura 2 (C e D) mostra ainda resultados da comparação dos métodos colorimétrico e titulométrico aplicados à amostras de esgoto sanitário bruto (P19 e P20) e de efluentes de dois reatores UASB (P21 e P22) em escala de demonstração. Percebe-se que para a maioria das amostras coletadas em duas campanhas distintas, os valores de DQO obtidos com a metodologia colorimétrica não foram significativamente diferentes quando comparados com os valores obtidos com o método titulométrico. Na maioria das amostras, a diferença observada encontra-se dentro da faixa de variação do método, e além disso não foi observado nenhum padrão ou regularidade nas diferenças, ou seja, não pode-se dizer que a DQO obtida pelo método titulométrico é sempre maior que àquela obtida pelo método colorimétrico ou vice-versa.

\section{DQO de solução de íons amônia e proteínas}

De acordo com o Standard Methods (APHA, 1998) a oxidação da maioria dos compostos durante o teste de DQO é de 95 a 100\% do valor teórico, e embora o teste de DQO seja frequentemente utilizado como indicação do teor de matéria orgânica reduzida presente em uma amostra, algumas substâncias reduzidas não são oxidadas pelo dicromato. Uma determinada substância pode não causar DQO por três razões principais: elevada volatilidade; elevado estado de oxidação; e resistência à oxidação. Substâncias voláteis (ex. tolueno) quando aquecidas durante o teste deixam o meio reacional contendo o dicromato para permanecerem no 

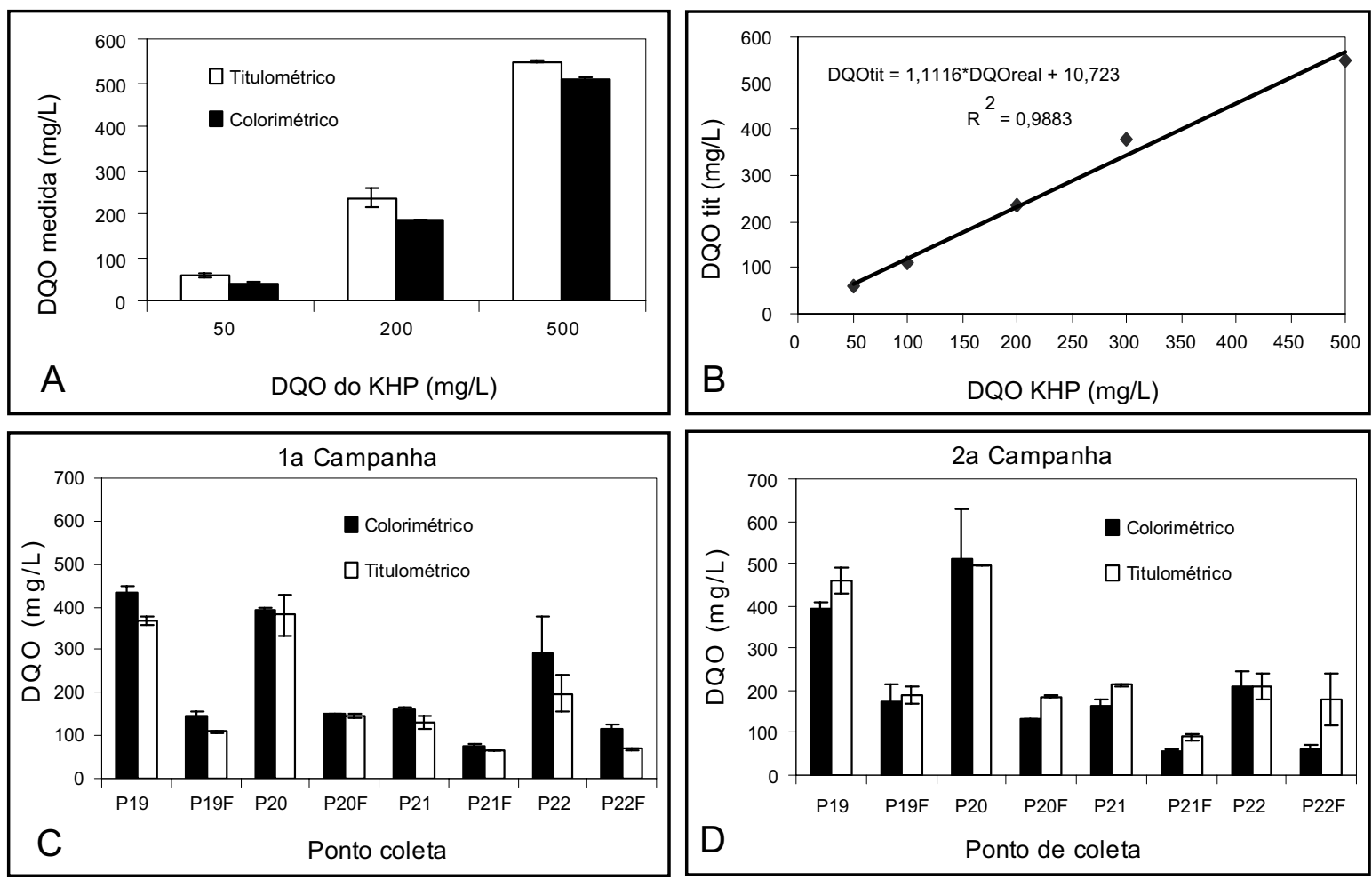

Figura 2 - Comparação dos métodos colorimétrico e titulométrico na determinação de DQO de solução padrão e de amostras brutas e filtradas (F) de afluente (PI9 e P20) e efluente (P2 I e P22) de reatores UASB

headspace do frasco de reação, enquanto que elementos no mais elevado estado de oxidação não podem ser oxidados. Algumas substâncias são naturalmente resistentes à oxidação pelo dicromato, como é o caso da piridina (composto aromático com um anel de 5 carbonos e 1 nitrogênio) e do ácido trifluoroacético (Vogel et al, 2000).

De acordo com o Standard Methods, alguns compostos podem ser oxidados de forma mais efetiva quando o catalisador sulfato de prata $\left(\mathrm{Ag}_{2} \mathrm{SO}_{4}\right)$ é adicionado ao meio reacional. Como a prata reage com haletos $\left(\mathrm{Cl}^{-}, \mathrm{Br}^{-}, \mathrm{I}^{-}\right)$para formar precipitados, a presença desses sais pode interferir negativamente no teste por reduzir a quantidade efetiva de catalisador em solução. Por outro lado, o íon cloreto pode ser oxidado a cloro $\left(\mathrm{Cl}_{2}\right)$ durante o teste, exercendo DQO. De acordo com o Standard Methods a interferência causada pelos cloretos pode ser minimizada pela adição de sulfato de mercúrio $\left(\mathrm{HgSO}_{4}\right)$ para formar o precipitado $\mathrm{HgCl}_{2}$; e a despeito dos problemas ambientais e/ou gerenciais decorrentes da disposição final do resíduo da DQO, o sulfato de mercúrio é adicionado à solução reagente usada na maioria dos laboratórios que realizam o teste de DQO.

No teste de DQO, o principal agente redutor é o carbono orgânico, i.e., ligado covalentemente a si próprio ou outros elementos. Nesse caso o carbono reduzido é oxidado a $\mathrm{CO}_{2}$ consumindo equivalentes de dicromato. Se outros elementos constituintes da matéria orgânica estiverem em estado reduzido, eles também podem causar DQO, a depender do elemento e do seu estado de oxidação. Sendo assim, durante o teste de DQO, o nitrogênio orgânico pode ser convertido a íon amônium $\left(\mathrm{NH}_{4}^{+}\right)$, a nitrato $\left(\mathrm{NO}_{3}^{-}\right)$ou a nitrogênio gasoso $\left(\mathrm{N}_{2}\right)$, a depender do estado de oxidação do nitrogênio no composto nitrogenado (Sawyer \& Mccarty, 1985). Segundo Vogel et al, (2000), se o nitrogênio estiver presente em um composto nas formas nitro $\left(-\mathrm{NO}_{2}\right)$, ou azo $(-\mathrm{N}=\mathrm{N}-)$ ele será respectivamente oxidado a nitrato $\left(\mathrm{NO}_{3}{ }^{-}\right)$ e nitrogênio molecular $\left(\mathrm{N}_{2}\right)$, consumindo dessa forma dicromato e exercendo DQO. Por sua vez, se o nitrogênio estiver presente como grupo amino $\left(-\mathrm{NH}_{2}\right)$ como no caso das proteínas, ele será, durante o teste de DQO, apenas hidrolizado a íons amônia $\left(\mathrm{NH}_{4}^{+}\right)$. Como não há, nesse caso, alteração no número de oxidação do nitrogênio (-3), não há consumo de dicromato nem demanda de DQO. Embora o Standard Methods saliente que os íons amônia não podem ser oxidados pelo dicromato, há controvérsia a respeito da sua oxidação, principalmente na presença de íons cloretos, e os experimentos que se seguem objetivaram investigar a concentração mínima de cloretos necessária para causar a oxidação dos íons amônia.

Uma simulação de oxidação do íon $\mathrm{NH}_{4}^{+}$a $\mathrm{NO}_{3}^{-}$pelo $\mathrm{Cr}_{2} \mathrm{O}_{7}^{2-}$ (reduzido a $\mathrm{Cr}^{3+}$ durante o teste), foi realizada para demonstrar o que ocorre na etapa de digestão durante a análise de DQO. A reação de oxi-redução é representada pela Equação 1.

$$
\begin{array}{lr}
1 / 8 \mathrm{NH}_{4}^{+}+3 / 8 \mathrm{H}_{2} \mathrm{O} \rightarrow 1 / 8 \mathrm{NO}_{3}^{-}+5 / 4 \mathrm{H}^{+}+\mathrm{e}^{-} & \text {(semi-reação doação e }) \\
1 / 6 \mathrm{Cr}_{2} \mathrm{O}_{7}^{2-}+\mathrm{e}^{-}+7 / 3 \mathrm{H}^{+} \rightarrow 1 / 3 \mathrm{Cr}^{3+}+7 / 6 \mathrm{H}_{2} \mathrm{O} & (\text { semi-reação aceitação e }) \\
\hline 1 / 8 \mathrm{NH}_{4}^{+}+1 / 6 \mathrm{Cr}_{2} \mathrm{O}_{7}^{2-}+13 / 12 \mathrm{H}^{+} \rightarrow 1 / 8 \mathrm{NO}_{3}^{-}+1 / 3 \mathrm{Cr}^{3+}+19 / 24 \mathrm{H}_{2} \mathrm{O} & \Delta \mathrm{G}^{\circ}=-43,3 \mathrm{~kJ} / \mathrm{mol}
\end{array}
$$


Embora a Equação 1 seja espontânea $\left(\Delta \mathrm{G}^{\circ}<0\right)$ nas condições padrão ( $\mathrm{T}=273 \mathrm{~K}, \mathrm{p}=1 \mathrm{~atm}$ ), é possível que a reação não seja espontânea nas condiçôes de digestão empregadas no teste de DQO. A Figura 3 apresenta uma simulação da variação do $\Delta \mathrm{G}$, corrigido para as condiçôes do teste conforme a equação 2 , em função da concentração inicial de íons amônia e do grau de oxidação durante o teste. Para efetuar a correção é necessário conhecer a temperatura $\left(150{ }^{\circ} \mathrm{C}\right)$ e as concentraçôes iniciais de reagentes $\left(\mathrm{Cr}_{2} \mathrm{O}_{7}{ }^{2-}=\right.$ $9,5 \times 10^{-3}$ mol.L $\mathrm{L}^{-1}, \mathrm{H}^{+}=10^{-1}$ mol. $\mathrm{L}^{-1} \mathrm{e}$ $\mathrm{NH}_{4}^{+}$variou de 0 a $6,7 \times 10^{-3} \mathrm{~mol} / \mathrm{L}$ ) bem como calcular a concentração de equilíbrio dos produtos, o que foi feito a partir das relações estequiométricas e do grau de conversão adotado.

$$
\Delta \mathrm{G}=\Delta \mathrm{G}^{0}+\mathrm{R} . \mathrm{T} \cdot \ln \frac{\left[\mathrm{NO}_{3}^{-}\right]^{\frac{1}{8}} \cdot\left[\mathrm{Cr}^{3+}\right]^{\frac{1}{3}} \cdot\left[\mathrm{H}_{2} \mathrm{O}\right]^{\frac{19}{24}}}{\left[\mathrm{NH}_{4}^{+}\right]^{\frac{1}{8}} \cdot\left[\mathrm{Cr}_{2} \mathrm{O}_{7}^{2-}\right]^{\frac{1}{6}} \cdot\left[\mathrm{H}^{+}\right]^{\frac{13}{12}}}
$$

A Figura 3 mostra que, para a faixa de concentração de 1 a $120 \mathrm{mg} / \mathrm{L}$ de $\mathrm{NH}_{4}^{+}$, a oxidação dos íons amônia é termodinamicamente favorável para diferentes graus de oxidação (de 1 a 99,99\%). Percebe-se que a medida que a concentração de íons amônia aumenta, há uma diminuição do valor (em módulo) de $\Delta \mathrm{G}$ da reação. É possível que a reação passe a ser não espontânea com valores elevados de íons amônia, entretanto para concentrações de íons amônia

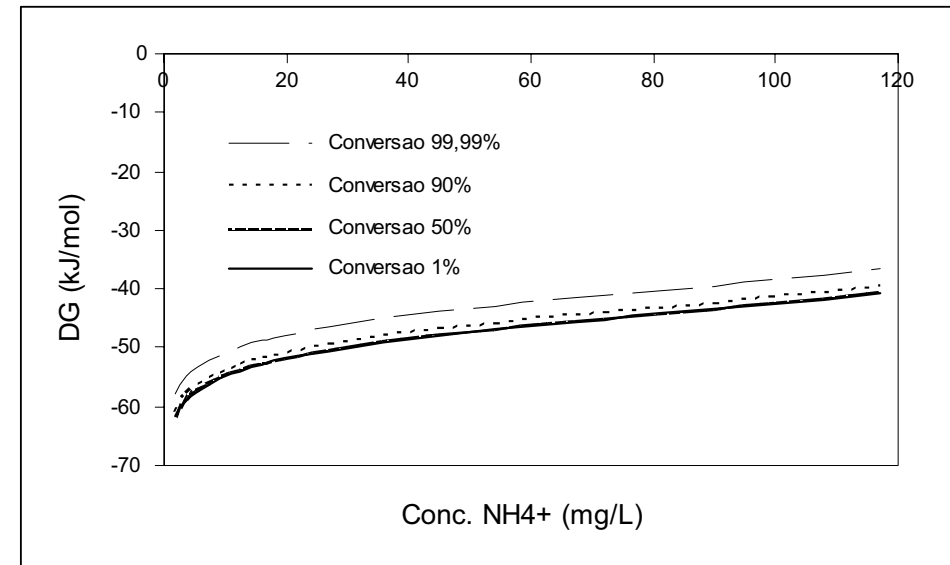

Figura 3 - Simulação da variação de energia livre durante o teste de DQO para diferentes concentrações de íons amônio

maiores que $117 \mathrm{mg} / \mathrm{L}$ (dentro do frasco de DQO), o reagente dicromato passa a ser o reagente limitante. Dessa forma, qualquer íon amônia em excesso não deveria ser oxidado pura e simplesmente devido a falta de agente oxidante.

Embora o estudo teórico tenha mostrado que o íon amônia pode ser oxidado durante o teste, os resultados experimentais mostram o contrário. A Figura 4 apresenta resultados de um experimento realizado para se determinar a DQO de solução padrão de íons amonium $\left(\mathrm{NH}_{4}^{+}\right)$ e de proteínas. Ambos ensaios foram realizados pelo método colorimétrico e cada ponto na curva representa a média de triplicatas analisadas.

A Figura 4 mostra que a DQO exercida pela proteína caseína foi diretamente proporcional a sua concentração, resul- tando em um coeficiente estequiométrico médio de 1,27 mgDQO/mgCaseína. $\mathrm{O}$ valor determinado experimentalmente aproxima-se do valor obtido teoricamente quando se considera a DQO teórica resultante da oxidação de uma proteína de fórmula genérica $\mathrm{C}_{16} \mathrm{H}_{24} \mathrm{O}_{5} \mathrm{~N}_{4}$.

Na Equação 3 considerou-se a conversão do nitrogênio orgânico em $\mathrm{NH}_{4}^{+}$, e dessa forma o consumo de oxigênio é devido apenas à oxidação da parte carbonácea constituinte das proteínas. A Equação 3 mostra que $1 / 66 \mathrm{~mol}$ de $\mathrm{C}_{16} \mathrm{H}_{24} \mathrm{O}_{5} \mathrm{~N}_{4}$ consome $1 / 4 \mathrm{~mol} \mathrm{de} \mathrm{O}_{2}$, ou seja, $1 \mathrm{mg}$ de proteína consumiria teoricamente 1,5 mg de DQO. Pela Equação 4 percebe-se que se o íon amônia fosse oxidado durante o teste de DQO,

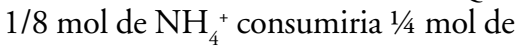

$$
\begin{array}{ll}
1 / 66 \mathrm{C}_{16} \mathrm{H}_{24} \mathrm{O}_{5} \mathrm{~N}_{4}+31 / 66 \mathrm{H}_{2} \mathrm{O} \rightarrow 12 / 66 \mathrm{CO}_{2}+4 / 66 \mathrm{NH}_{4}^{+}+4 / 66 \mathrm{HCO}_{3}^{-}+\mathrm{H}^{+}+\mathrm{e}^{-} & \begin{array}{l}
\text { (semi-reação doação } \left.\mathrm{e}^{-}\right) \\
\text {(semi-reação aceitação e })
\end{array} \\
\frac{1 / 4 \mathrm{O}_{2}+\mathrm{e}^{-}+\mathrm{H}^{+} \rightarrow 1 / 2 \mathrm{H}_{2} \mathrm{O}}{1 / 66 \mathrm{C}_{16} \mathrm{H}_{24} \mathrm{O}_{5} \mathrm{~N}_{4}+1 / 4 \mathrm{O}_{2} \rightarrow 2 / 66 \mathrm{H}_{2} 12 / 66 \mathrm{CO}_{2}+4 / 66 \mathrm{NH}_{4}^{+}+4 / 66 \mathrm{HCO}_{3}^{-}} & \begin{array}{l}
\text { (Reação global) } \\
1 / 8 \mathrm{NH}_{4}^{+}+3 / 8 \mathrm{H}_{2} \mathrm{O} \rightarrow 1 / 8 \mathrm{NO}_{3}^{-}+5 / 4 \mathrm{H}^{+}+\mathrm{e}^{-} \quad(\text { semi-reação doação e })
\end{array} \\
\frac{1 / 4 \mathrm{O}_{2}+\mathrm{e}^{-}+\mathrm{H}^{+} \rightarrow 1 / 2 \mathrm{H}_{2} \mathrm{O}}{1 / 8 \mathrm{NH}_{4}^{+}+1 / 4 \mathrm{O}_{2} \rightarrow 1 / 8 \mathrm{H}_{2} \mathrm{O}+1 / 8 \mathrm{NO}_{3}^{-}+1 / 4 \mathrm{H}^{+} \quad(\text { Reação global })}
\end{array}
$$

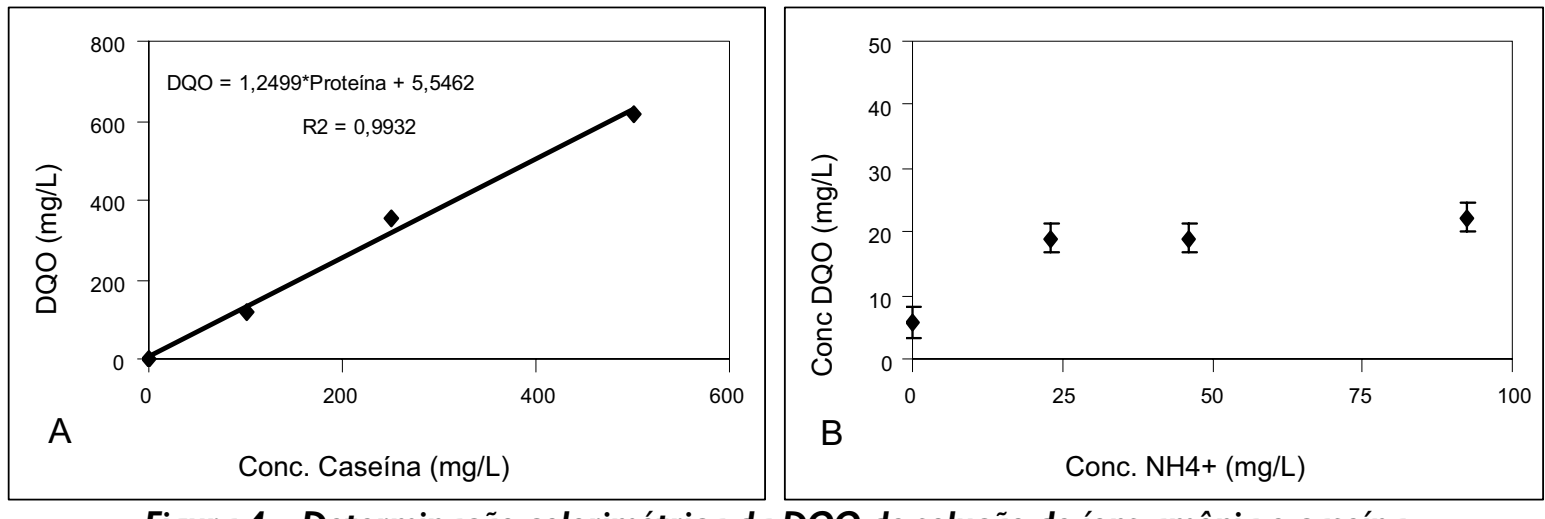

Figura 4 - Determinação colorimétrica da DQO de solução de íons amônia e caseína 
$\mathrm{O}_{2}$, ou seja, $1 \mathrm{mg}$ de íon amônio consumiria teoricamente $3,55 \mathrm{mgO}_{2}$.

A Figura 4 mostra que os íons amônia não exerceram significativa DQO mesmo quando presentes na concentração de $100 \mathrm{mg} / \mathrm{L}$, o que representaria, de acordo com a equação 1 uma DQO teórica de $355 \mathrm{mg} \mathrm{O} / \mathrm{L}$. De acordo com o Standard Methods, os íons amônia, presentes no esgoto ou liberados durante a oxidação de proteínas, só são oxidados na presença de íons cloretos. Embora o Standard Methods não explique o porque desse fato, a presença de cloretos pode facilitar indiretamente a oxidação dos íons amônia devido à formação de cloraminas durante o teste. Cloretos são oxidados a cloro molecular $\left(\mathrm{Cl}_{2}\right)$ durante o teste se a solução de digestão não contém quantidades estequiométricas de sulfato de mercúrio, conforme discutido anteriormente. A formação de cloro durante o teste e a presença de íons amônia podem levar à formação de cloraminas, que poderiam então ser oxidadas pelo dicromato. Sendo assim, outro experimento foi feito para se verificar a influência da concentração de cloretos na DQO de íons amônia. Foi usado o método colorimétrico com solução de dicromato concentrada, e os resultados são apresentados na Figura 5.

Observa-se que a DQO medida é de fato maior quando há uma maior presença de cloretos (Figura 5A e 5B). $\mathrm{Na}$ ausência de íons amônia e presença de $1000 \mathrm{mg} / \mathrm{L}$ de cloretos a DQO medida foi de aproximadamente $89 \mathrm{mg} / \mathrm{L}$ (Figura 5A), indicando a demanda causada exclusivamente pelos íons cloretos (100 $\mathrm{mg} \mathrm{Cl}^{-}=8,9 \mathrm{mg} \mathrm{DQO}$ ). A DQO teórica de $1000 \mathrm{mg} / \mathrm{L}$ de cloretos é $225 \mathrm{mg} \mathrm{O}_{2} / \mathrm{L}$ e o valor obtido expe- rimentalmente $\left(89 \mathrm{mgO}_{2} / \mathrm{L}\right)$ mostra que a presença de sulfato de mercúrio minimizou a DQO devido a cloretos, mas não a eliminou. Quando a concentração de cloretos foi reduzida para $750 \mathrm{mg} / \mathrm{L}$ a DQO exercida pelos cloretos deveria ser, proporcionalmente, de $66,7 \mathrm{mg} / \mathrm{L}$. Entretanto o valor medido foi de $90 \mathrm{mg} / \mathrm{L}$, sugerindo que a oxidação de íons amônia, presentes na concentração de $50 \mathrm{mg} / \mathrm{L}$, foi responsável pela diferença de DQO observada (Figura 5A). Em outras palavras, a presença de $50 \mathrm{mg} / \mathrm{L}$ de íons amônia teria exercido uma DQO de aproximadamente $23,2 \mathrm{mg} / \mathrm{L}$, na presença de $750 \mathrm{mg} / \mathrm{L}$ de cloretos.

O experimento foi repetido (Figura 5B) aumentando-se as concentrações de cloretos e íons amônia, e embora os valores de DQO obtidos tenham sido menores, observou-se a mesma tendência do primeiro experimento. $\mathrm{Na}$ presença de $2000 \mathrm{mg} / \mathrm{L}$ de cloretos, a DQO exercida foi de apenas $51 \mathrm{mg} / \mathrm{L}$ (Figura 5B), enquanto que no primeiro teste (Figura 5A) a presença de $1000 \mathrm{mg} / \mathrm{L}$ resultou em uma DQO de $89 \mathrm{mg} / \mathrm{L}$. Para tentar dirimir as dúvidas levantadas nos experimentos anteriores, um outro experimento foi realizado.

A Figura 6A mostra o resultado de DQOs de soluçōes contendo íons amônia e cloretos em diferentes combinaçōes. $\mathrm{Na}$ ausência de cloretos e íons amônia, a DQO medida foi menor que $10 \mathrm{mg} / \mathrm{L}$ e esse cenário representa o 'branco'. A Figura 6A mostra $1000 \mathrm{mg} / \mathrm{L}$ de cloretos resultaram em uma DQO média de $60 \mathrm{mg} / \mathrm{L}$, enquanto que $50 \mathrm{mg} / \mathrm{L}$ de cloretos a DQO medida foi em média $40 \mathrm{mg} / \mathrm{L}$. Esses resultados parecem indicar o efeito dúbio causado pelos cloretos. $\mathrm{O}$ excesso de cloretos pode por um lado exercer DQO devido à formação de cloro, mas pode por outro precipitar com o catalisador e formar $\mathrm{AgCl}$, diminuindo assim a capacidade de oxidação durante o teste. De fato mais precipitado branco foi observado no fundo do tubo-teste de DQO no segundo experimento em que cloretos foram adicionados em concentração maior. A Figura $6 \mathrm{~A}$ mostra que na presença de apenas $50 \mathrm{mg} / \mathrm{L}$ de íons amônia a DQO medida foi em média $8 \mathrm{mg} / \mathrm{L}$, ao passo que $50 \mathrm{mg} / \mathrm{L}$ de íons amônia na presença de $50 \mathrm{mg} / \mathrm{L}$ de cloretos resultou em uma DQO média de $40 \mathrm{mg} / \mathrm{L}$. O aumento na concentração de cloretos para $1000 \mathrm{mg} / \mathrm{L}$ causou um aumento considerável na DQO da solução de $50 \mathrm{mg} / \mathrm{L}$ de íons amônia, uma vez que a DQO média aumentou para $105 \mathrm{mg} / \mathrm{L}$. Como a DQO na presença de apenas cloretos na concentração de $1000 \mathrm{mg} / \mathrm{L}$ foi de $60 \mathrm{mg} / \mathrm{L}$, esses resultados indicam que os $50 \mathrm{mg} / \mathrm{L}$ de íons amônia causaram DQO somente quando grande quantidade de cloretos estava presente, nesse caso $1000 \mathrm{mgCl} / \mathrm{L}$.

Kim (1989) observou que os íons amônia não foram oxidados na presença de cloretos $(500 \mathrm{mg} / \mathrm{L})$ utilizando-se uma solução de dicromato de potássio 0,025 N. Entretanto o aumento da concentração de dicromato para 0,25 $\mathrm{N}$ resultou em oxidação significativa dos íons amônia, indicando que a concentração da solução de dicromato é o fator mais importante na oxidação dos íons amônia na presença de cloretos. $\mathrm{O}$ autor mostrou ainda que a despeito da adição de mercúrio na proporção ideal (10:1), houve aumento significativo da DQO da solução de cloretos e amônia, sugerindo que a complexação dos cloretos não previniu a oxidação da amônia.

Como a concentração de cloretos no esgoto sanitário encontra-se na faixa
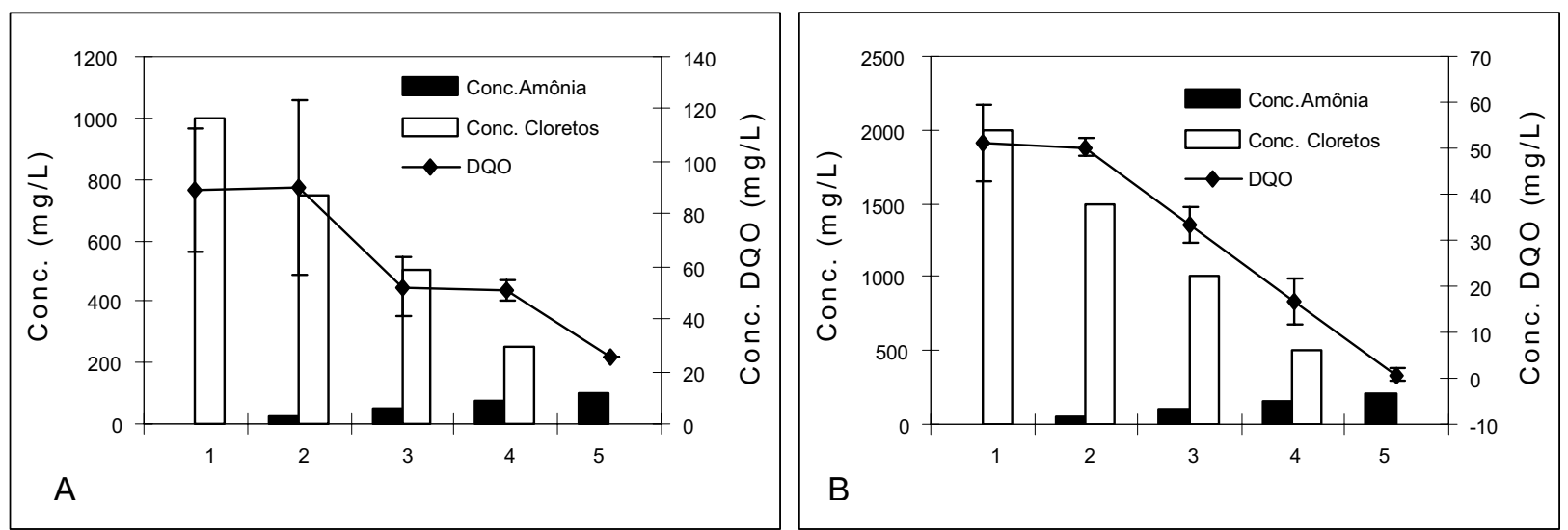

Figura 5 - Influência de cloretos (0 a 2000 mg/L) na DQO do íon amônio (0 a 50 mg/L) 

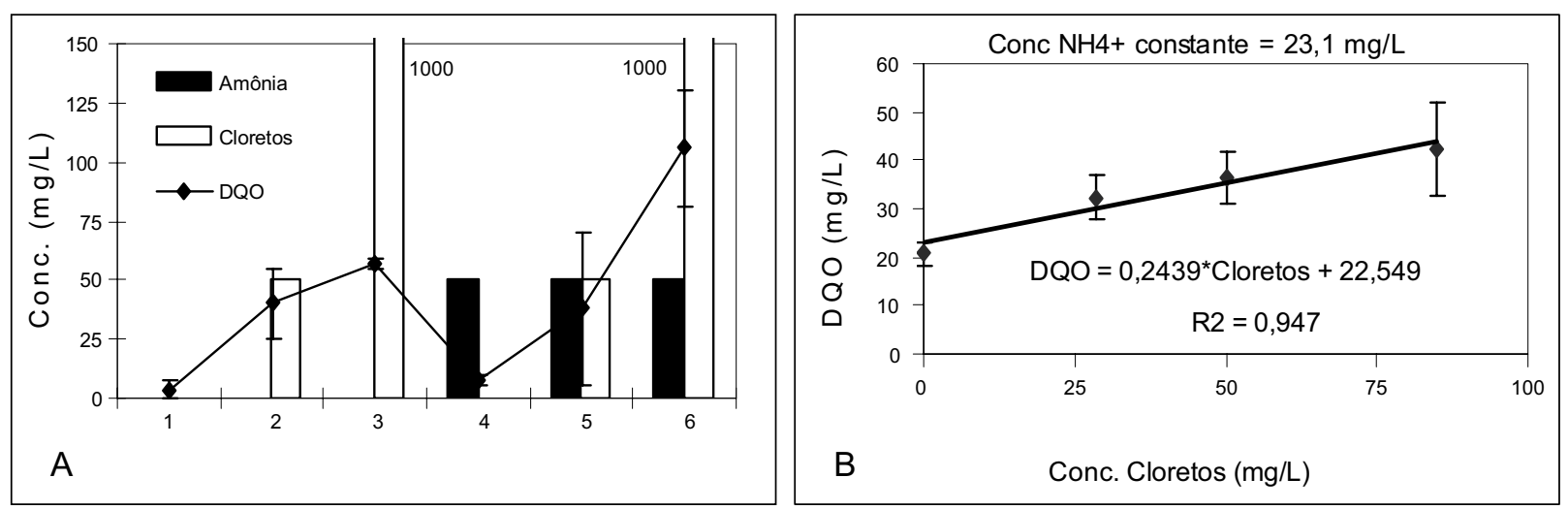

Figura 6 - DQO de soluções contendo cloreto e íons amônia em diferentes concentrações

de 30 a $100 \mathrm{mg} / \mathrm{L}$ (Metcalf \& Eddy, 1991), outro experimento foi realizado fixando-se a concentração de íons amônia em 23,1 mg/L e variando-se a concentração de cloretos dentro da faixa típica observada em cidades não litorâneas. Os resultados, apresentados na Figura 6B, mostram que houve pouco aumento no valor da $\mathrm{DQO}$ da solução de íons amônia à medida que a concentração de cloretos aumentou de 30 para $85 \mathrm{mg} / \mathrm{L}$. Como discutido anteriormente, é provável que o pequeno aumento de DQO observado tenha sido mais relacionado à oxidação dos cloretos do que à oxidação dos íons amônia.

\section{Influência da presença de sulfetos e ferro no teste de DQO}

Como discutido anteriormente, todas substâncias passíveis de oxidação pelo dicromato, orgânicas e inorgânicas, contribuirão para a DQO de uma amostra. Substâncias inorgânicas como sulfeto, nitrito, tiosulfato, $\mathrm{Fe}^{2+}, \mathrm{Mn}^{2+}$, $\mathrm{Cu}^{+}, \mathrm{Ni}^{2+}, \mathrm{Co}^{2+}$ e cloretos podem ser oxidados pelo dicromato, contribuindo assim para a DQO nas amostras analisadas. Dessa forma, o uso do parâmetro DQO para monitoramento da eficiência de um sistema de tratamento na remoção de matéria orgânica poluente só pode ser feito levando-se em conta os efeitos causados pelos compostos inorgânicos reduzidos presentes.

Nesse artigo a quantificação da influência da presença de sulfetos na DQO foi verificada em dois experimentos (Figura 7A e 7B) utilizando-se o método colorimétrico descrito anteriormente. O sulfeto é uma substância reduzida, e os resultados apresentados na Figura 7 mostram que, ao contrário dos íons amônia, o sulfeto foi extensivamente oxidado durante o teste de DQO. Embora o aumento da DQO tenha sido linear com o aumento da concentração de sulfeto, os coeficientes estequiométricos obtidos experimentalmente (1,1 e 1,2 gDQO/gSulfeto) diferem significativamente do valor teórico, haja vista que a oxidação completa do sulfeto a sulfato resulta em coeficiente estequiométrico de $2 \mathrm{gDQO} / \mathrm{gSulfeto.}$

Uma possível explicação para a discrepante observação experimental reside no fato de que durante o teste de $\mathrm{DQO}$ o $\mathrm{pH}$ é reduzido para valores próximos a 1 com a adição de ácido sulfúrico concentrado. $\mathrm{O}$ baixo $\mathrm{pH}$ pode resultar na perda de parte do sulfeto presente antes do início do teste, e resultar ainda no seu desprendimento, durante o aquecimento, para o headspace do frasco de reação, o que diminuiria o seu contato com a solução de dicromato, reduzindo consequentemente o valor da DQO medida.

Segundo Kylefors et al (2003) a propensão de substâncias orgânicas à oxidação pode mudar em função da especiação química da substância em questão. Em sistemas anaeróbios a maior parte dos sulfetos está presente na forma de sais metálicos de baixíssima solubilidade, e os resultados apresentados na Figura 8 foram obtidos de experimentos que simularam a presença de sulfetos precipitado pelos íons ferroso $\left(\mathrm{Fe}^{2+}\right)$ e férrico $\left(\mathrm{Fe}^{3+}\right)$.

A Figura 8A mostra que na ausência de $\mathrm{Fe}^{3+}$ a DQO de uma solução contendo $200 \mathrm{mg} / \mathrm{L}$ de sulfeto foi de $238 \mathrm{mg} / \mathrm{L}$, resultando em um coeficiente estequiométrico semelhante ao obtido anteriormente (Figura 7). A adição, à solução de sulfeto, de concen- traçôes estequiométricas de $\mathrm{Fe}^{3+}$ causou a precipitação instantânea de $\mathrm{Fe}_{2} \mathrm{~S}_{3}$ e resultou na redução do coeficiente estequiométrico de $1,2 \mathrm{gDQO} / \mathrm{gSulfeto}$ para $0,98 \mathrm{gDQO} / \mathrm{gSulfeto.} \mathrm{Esses}$ resultados sugerem que muito embora o precipitado $\mathrm{Fe}_{2} \mathrm{~S}_{3}$ seja solubilizado devido às condiçôes de baixo $\mathrm{pH}$ impostas durante o teste de $\mathrm{DQO}$, a presença de $\mathrm{Fe}^{3+}$ reduziu em $18 \%$, em média, a DQO causada pelos íons sulfeto.

A Figura $8 \mathrm{~B}$ e a Tabela 1 mostram que a DQO experimental de uma solução contendo $6,25 \mathrm{mM}$ de $\mathrm{Fe}^{2+}(350 \mathrm{mg} / \mathrm{L})$ foi apenas $46 \%$ do valor teórico. Embora não se saiba ao certo porque os íons ferroso não foram oxidados pelo dicromato, sabe-se que o Fe II em ambientes naturais ácidos é quimicamente estável e não pode ser extensivamente oxidado pelo oxigênio molecular (Schippers et al, 1996). Talvez esta estabilidade do Fe II em baixo pH seja a explicação para sua menor oxidação pelo dicromato. De forma similar, a DQO experimental de uma solução contendo $6,25 \mathrm{mM}$ de sulfeto $(200 \mathrm{mg} / \mathrm{L})$ foi bem menor que o valor teórico, e a Tabela 1 mostra que na presença de quantidades estequiométricas de $\mathrm{Fe}^{2+}$ a DQO medida foi em média apenas $27 \%$ do valor teórico.

Para um esgoto doméstico que contenha de 20 a $50 \mathrm{mg} / \mathrm{L}$ de sulfato $\left(\mathrm{SO}_{4}{ }^{2-}\right)$ (Metcalf \& Eddy, 1991), a redução total dos sulfatos durante o tratamento anaeróbio, produziria de 7 a $17 \mathrm{mg} / \mathrm{L}$ de sulfeto $\left(\mathrm{S}^{2-}\right)$. No $\mathrm{pH}$ igual a 7 , aproximadamente $50 \%$ do sulfeto encontra-se na forma iônica (HS-), enquanto os outros $50 \%$ encontramse na forma $\mathrm{H}_{2} \mathrm{~S}_{(\mathrm{aq})}$ passíveis de serem liberados para a fase gasosa. Portanto, assumindo-se que apenas $50 \%$ do sulfeto 

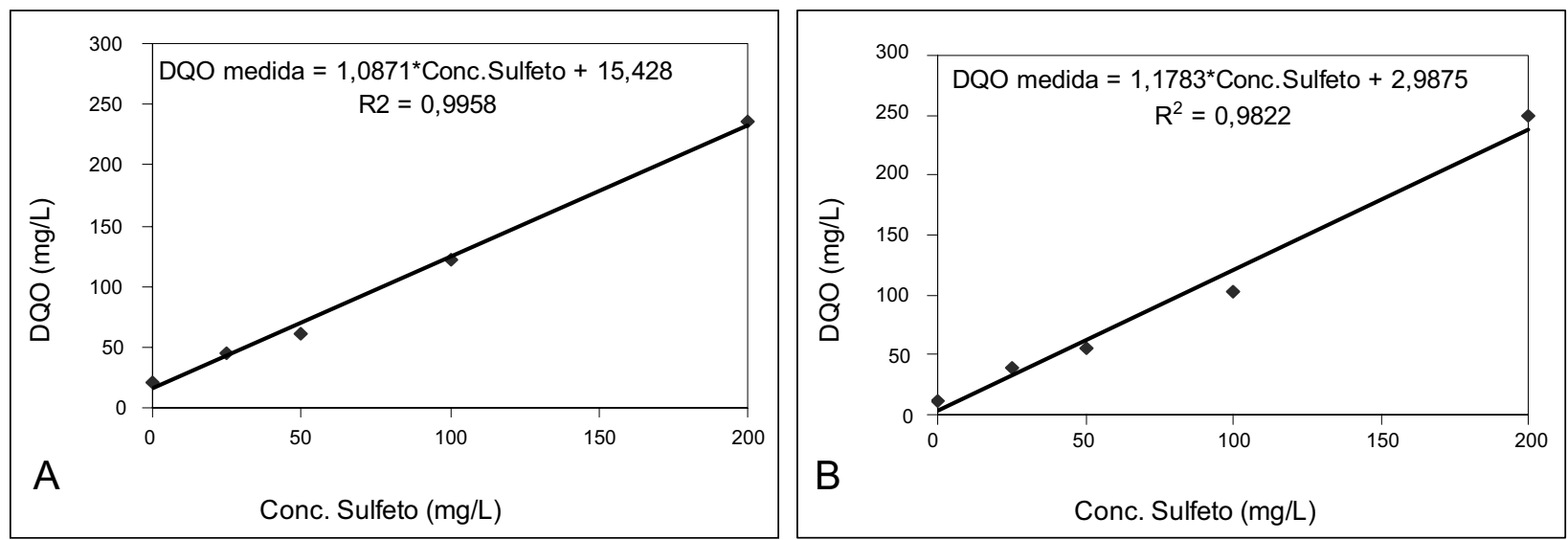

Figura 7 - DQO de solução padrão de sulfeto de sódio
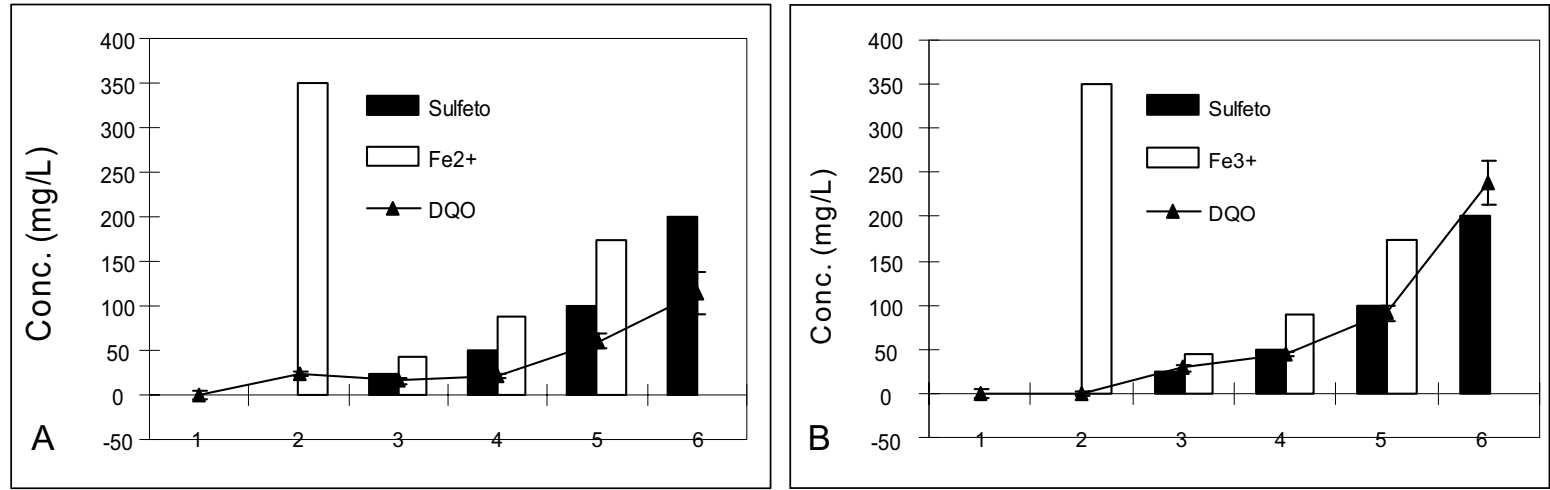

Figura 8 - Efeito da presença de $\mathrm{Fe}^{2+}$ e $\mathrm{Fe}^{3+}$ na DQO do sulfeto

Tabela I - DQO teórica e medida de soluções contendo sulfeto e $\mathrm{Fe}^{2+}$

\begin{tabular}{ccccc}
\hline Frasco & $\begin{array}{c}\text { Fe II } \\
(\mathrm{mM})\end{array}$ & $\begin{array}{c}\text { Sulfeto } \\
(\mathrm{mM})\end{array}$ & $\begin{array}{c}\text { DQO teórica } \\
\left(\mathrm{mgO}_{2} / \mathrm{L}\right)^{1}\end{array}$ & $\begin{array}{c}\text { DQO medida } \\
\left(\mathrm{mgO}_{2} / \mathrm{L}\right)\end{array}$ \\
\hline 1 & 0 & 0 & 0 & $0 \pm 4$ \\
2 & 6,25 & 0 & 49 & $23 \pm 5$ \\
3 & 0,78 & 0,78 & 56 & $16 \pm 4$ \\
4 & 1,56 & 1,56 & 112 & $21 \pm 1$ \\
5 & 3,12 & 3,12 & 224 & $60 \pm 7$ \\
6 & 0 & 6,25 & 400 & $114 \pm 6$ \\
\hline
\end{tabular}

${ }^{1}$ Considerou-se os coeficientes estequiométricos teóricos $0,14 \mathrm{gDQO} / \mathrm{gFe}^{2+}$ e $2 \mathrm{gDQO} / \mathrm{gS}^{2}$.

formado causaria DQO na fase líquida, e assumindo ainda o coeficiente de conversão determinado experimentalmente (1,2 gDQO/gSulfeto), a formação de sulfetos em sistemas anaeróbios alimentados com esgoto doméstico contribuiria de 5 a $11 \%$ da DQO filtrada efluente, assumindo-se que a DQO total do efluente anaeróbio seja de $150 \mathrm{mg} / \mathrm{L}$ e que a fração dissolvida corresponde a $60 \%$ da DQO total.

Desta forma, em efluentes industriais que contém matéria orgânica oxidável e elevadas concentrações de sulfato, como é o caso de efluentes de curtume e de indústrias químicas que empregam sulfonação de óleos, a análise da eficiência de um sistema anaérobio não pode ser feita com base na DQO sem se levar em conta a produção de sulfetos durante o tratamento. A presença, no efluente do sistema de tratamento anaeróbio, de sulfetos e outros compostos inorgânicos reduzidos, pode resultar em reduzida eficiência de remoção de DQO ainda que a matéria orgânica afluente tenha sido eficientemente convertida durante o tratamento.

A presença de outros gases reduzidos em sistemas anaeróbios $\left(\mathrm{CH}_{4}\right.$ e $\left.\mathrm{H}_{2}\right)$ não deveria causar significativa DQO no efluente devido à pequena solubi- lidade desses gases na água. Embora uma maior concentração de metano e hidrogênio na fase líquida seja possível dentro de reatores pressurizados, a saída do efluente do reator resultaria em desprendimento desses gases da fase líquida devido à diminuição da pressão.

\section{Comparação da DQO teórica e experimental da matéria orgânica específica}

A determinação de coeficientes de conversão da matéria orgânica específica em DQO é importante para se determinar a contribuição relativa 
desses compostos para o valor DQO determinada em amostras ambientais. A regressão linear dos resultados obtidos e apresentados na Figura 9 mostram uma boa correlação entre o aumento na concentração de proteínas, carboidratos e lipídeos, e o aumento de DQO.

Os coeficientes estequiométricos determinados experimentalmente para carboidratos (1,01 gDQO/gGlicose) e proteínas (1,59 gDQO/gCaseína), são bastante próximos aos valores teóricos. Da equação 5 deduz-se que $7,5 \mathrm{~g}$ de carboidratos $\left(\mathrm{C}_{6} \mathrm{H}_{12} \mathrm{O}_{6}\right)$ consomem $8 \mathrm{~g}$ de $\mathrm{O}_{2}$, o que resulta em um coeficiente de conversão de 1,07 gDQO/gGlicose, e da equação 3 deduz-se que $5,33 \mathrm{~g}$ de proteínas $\left(\mathrm{C}_{16} \mathrm{H}_{24} \mathrm{O}_{5} \mathrm{~N}_{4}\right)$ consomem $8 \mathrm{~g}$ de $\mathrm{O}_{2}$, o que resulta em um coeficiente de conversão de 1,5 gDQO/gProteína. Já o valor do coeficiente determinado experimentalmente para lipídeos (1,55 gDQO/gÓleo) difere consideravelmente do valor teórico deduzido a partir da equação 6 , que considera 0 triglicerídeo ${ }^{1}$ do ácido graxo palmítico $\left(\mathrm{C}_{16} \mathrm{H}_{32} \mathrm{O}_{2}\right)$ um representante típico dos lipídeos.

De acordo com a equação 6 uma massa de 2,69 g de lipídeos $\left(\mathrm{C}_{51} \mathrm{H}_{98} \mathrm{O}_{6}\right)$ consumiria $8 \mathrm{~g}$ de $\mathrm{O}_{2}$, o que resultaria em um coeficiente de conversão de 2,97 gDQO/gLipídeo. Miron et al (2000) de fato utilizaram um coeficiente de conversão igual a 2,9 para lipídeos, valor semelhante ao coeficiente teórico obtido a partir da equação 6 .

Baker et al (1999) salientam que compostos hidrofóbicos tendem a apresentar DQO muito menor do que o valor teórico em função da sua adsorção nas paredes de recipientes, pipetas, ponteiras, etc. Embora a solução de lipídeos tenha sido preparada em meio ácido ou básico para favorecer sua hidrólise e consequente dissolução, é possível que parte do óleo não tenha sido emulsionado, explicando assim a discrepância observada entre os resultados práticos e o valor teórico. No primeiro experimento para determinação da DQO da
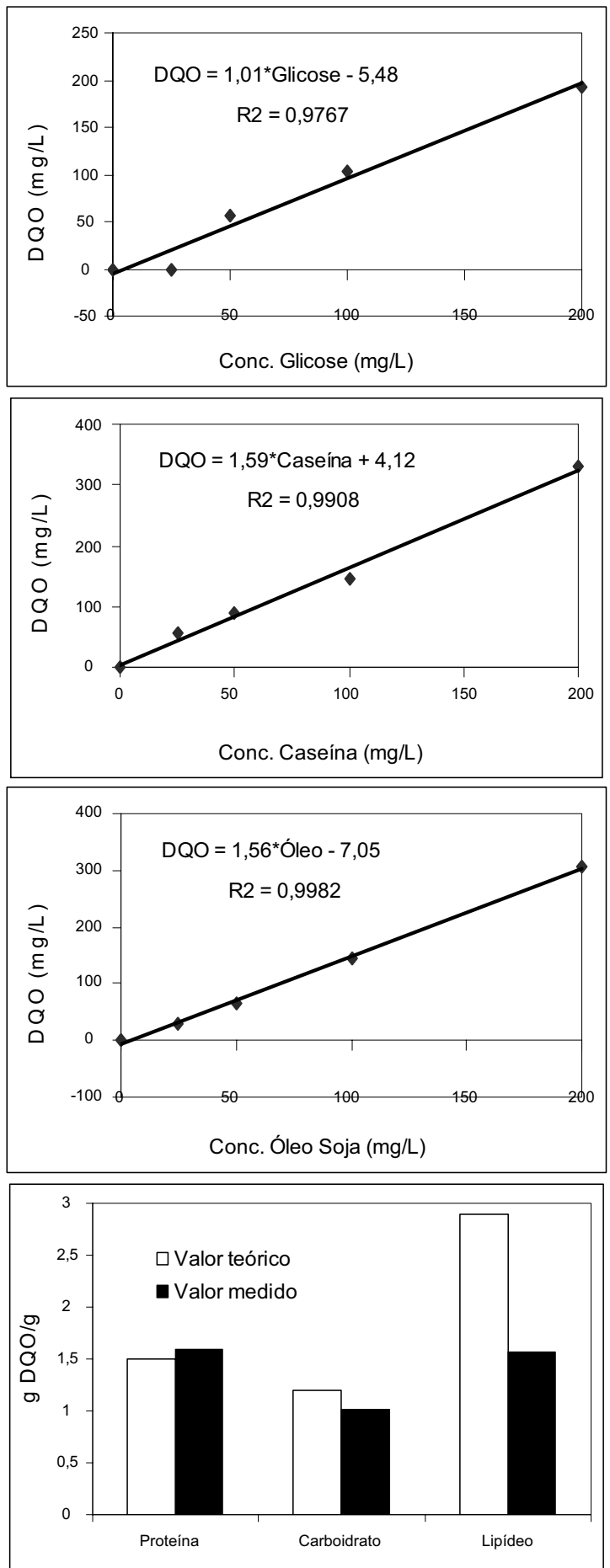

Figura 9 - Determinação experimental dos coeficientes de conversão de proteínas, carboidratos e lipídeos em DQO

$1 / 24 \mathrm{C}_{6} \mathrm{H}_{12} \mathrm{O}_{6}+1 / 4 \mathrm{H}_{2} \mathrm{O} \rightarrow 1 / 4 \mathrm{CO}_{2}+\mathrm{H}^{+}+\mathrm{e}^{-}$

(semi-reação doação e $\left.\mathrm{e}^{-}\right)$

$1 / 4 \mathrm{O}_{2}+\mathrm{e}^{-}+\mathrm{H}^{+} \rightarrow 1 / 2 \mathrm{H}_{2} \mathrm{O}$

$1 / 24 \mathrm{C}_{6} \mathrm{H}_{12} \mathrm{O}_{6}+1 / 4 \mathrm{O}_{2} \rightarrow 1 / 4 \mathrm{H}_{2} \mathrm{O}+1 / 4 \mathrm{CO}_{2}$

(semi-reação aceitação e $\left.\mathrm{e}^{-}\right)$

(Reação global)

(semi-reação doação e') (semi-reação aceitação e $\mathrm{e}^{-}$

$\begin{array}{ll}\frac{1 / 4}{4} \mathrm{O}_{2}+\mathrm{e}^{-}+\mathrm{H}^{+} \rightarrow 1 / 2 \mathrm{H}_{2} \mathrm{O} & \text { (semi-reação ace } \\ 1 / 290 \mathrm{C}_{51} \mathrm{H}_{98} \mathrm{O}_{6}+1 / 4 \mathrm{O}_{2} \rightarrow 49 / 290 \mathrm{H}_{2} \mathrm{O}+51 / 290 \mathrm{CO}_{2} & \text { (Reação global) }\end{array}$

${ }^{1}$ Representação química do triglicerídeo de ácido linoléico:

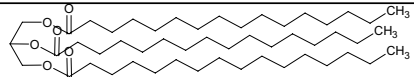


solução de óleo de soja, utilizou-se uma solução de $\mathrm{NaOH} 0,1 \mathrm{M}$ para solubilizar o triglicerídeo, e como a hidrólise não altera o número médio de oxidação do carbono do triglicerídeo, essa estratégia de solubilização não deveria influenciar na DQO resultante. Como o valor do coeficiente estequiométrico obtido no experimento com lipídeos foi muito inferior ao valor teórico, o ensaio foi repetido, utilizando-se desta vez $\mathrm{H}_{2} \mathrm{SO}_{4}$ (50\%) para solubilizar o óleo. Essa estratégia de solubilização também não deveria afetar a DQO resultante uma vez que a hidrólise ácida do triglicerídeo não muda o número médio de oxidação do carbono da molécula. A partir dos resultados do segundo experimento (dados não apresentados) obteve-se um coeficiente estequiométrico de $1,6 \mathrm{gDQO} / \mathrm{gÓleo} \mathrm{com} \mathrm{elevado} \mathrm{grau} \mathrm{de}$ ajuste $\left(R^{2}=0,9991\right)$. Esses resultados confirmam que o coeficiente estequiométrico experimental é em média $53 \%$ do valor calculado, e embora não se possa afirmar de forma categórica as razōes para tal discrepância, o valor experimental deve ser preferido para converter o teor de lipídeos em DQO.

\section{CONCLUSÃO}

Os resultados apresentados mostraram não haver diferenças significativas na determinação da DQO pelos métodos colorimétrico e titulométrico, e que embora a oxidação do íon amonium seja termodinamicamente favorável nas condiçōes do teste, os íons amônia de fato não exerceram DQO. Os íons amônia só causaram significativa DQO na presença de elevada concentração de cloretos $(\sim 1000 \mathrm{mg} / \mathrm{L})$, e uma hipótese levantada para explicar tal fato se baseia na formação de cloraminas durante o teste.

Os coeficientes de conversão da matéria orgânica específica em DQO, determinados experimentalmente, foram de 1,01 $\mathrm{gDQO} / \mathrm{gGlicose}$ para os carboidratos; $1,59 \mathrm{gDQO} / \mathrm{gCaseína}$ para as proteínas e 1,55 gDQO/gÓleo Soja para os lipídeos.

$\mathrm{O}$ artigo mostrou ainda que a $\mathrm{DQO}$ devido aos sulfetos (1,1 gDQO/gSulfeto) foi em média $60 \%$ do valor teórico. A presença de sulfeto combinado com Fe III $\left(\mathrm{Fe}_{2} \mathrm{~S}_{3}\right)$ reduziu em $18 \%$ a DQO causada pelos sulfetos, enquanto que o sulfeto combinado com o $\mathrm{Fe}$ II $(\mathrm{FeS})$ resultou em valores de DQO que foram, em média, $56 \%$ do valor teórico.
O resultados desse trabalho mostram que algumas substâncias reduzidas (lipídeos, sulfetos, íons amônia) não foram totalmente oxidadas durante o teste de DQO, fazendo a relação $\mathrm{DQO}_{\text {medida }} / \mathrm{DQO}_{\text {teórica }}$ se afastar da unidade. No caso de lançamento dessas substâncias no corpo receptor o impacto pode ser maior do que o previsto apenas pelo parâmetro DQO, uma vez que compostos não oxidados pelo dicromato durante o teste podem ser oxidados biologicamente (caso dos íons amônia e lipídeos) ou abioticamente (caso do sulfeto) pelo oxigênio dissolvido presente no corpo receptor.

\section{AGRADECIMENTOS}

SFA e SQS gostariam de agradecer ao CNPq a concessão das bolsas de Pós-Doc (Processos 15004/2004 e 150011/2004) para o desenvolvimento de atividades de pesquisa junto ao Departamento de Engenharia Sanitária e Ambiental (DESA) da UFMG.

\section{REFERÊNCIAS}

APHA, AWW, WEF. Standard methods for the examination of water and wastewater. $19^{\text {th }}$. Edition. Amercian Pub;ic Health Association, Washingtion, DC., 1995.

BAKER, J.R.; MILKE, M.W.; MIHELCIC, J.R. Relationship between chemical and theoretical oxygen demand for specific classes of organic chemicals. Water Research, v. 33, p. 327-334, 1999.

KIM, B. R. Effect of ammonia on COD analysis. Journal Water Pollution Control Federation (WPCF), v. 61, n. 5, p. 614- 617, 1989.

KYLEFORS, K.; ECKE, H.; LAGERKVIST, A. Accuracy of COD test for landfill leachates. Water, Air and Soil Pollution, v. 146, p. 153169, 2003.

METCALF \& EDDY, INC. Wastewater Engineering: treatment, disposal and reuse. $3^{\text {rd }} \mathrm{Ed}$. Singapore, McGraw-Hill, 1991.

MIRON, Y. et al. The role of sludge retention time in the hydrolysis and acidification of lipids, carbohydrates and proteins during digestion of primary sludge in CSTR systems. Water Research, v. 34, p. 1705-1713, 2000.

SAWYER, C. N. e McCARTY, P. L. Chemistry for Environmental Engineering. $3^{\text {rd }}$ Ed. McGrawHill, 1985.

SCHIPPERS, A.; JOZSA, P-G.; SAND, W. Sulfur chemistry in bacterial leaching of pyrite. Applied and Environmental Microbiology, v. 62, p. 3424-3431, 1996.

VOGEL, F.et al. The mean oxidation number of carbon (MOC) - usefull concept for describing oxidation processes. Water Research, v. 34, p. 2689-2702, 2000.

\section{Endereço para correspondência:}

\section{Sérgio F. de Aquino \\ Departamento de Química Instituto de Ciências Exatas e Biológicas \\ Universidade Federal de Ouro \\ Preto - UFOP \\ 35400-000 Ouro Preto - MG - \\ Brasil}

Tel.: (3I) 3559-I837

Fax: (3I) 3559-I636

Email: sergio@iceb.ufop.br

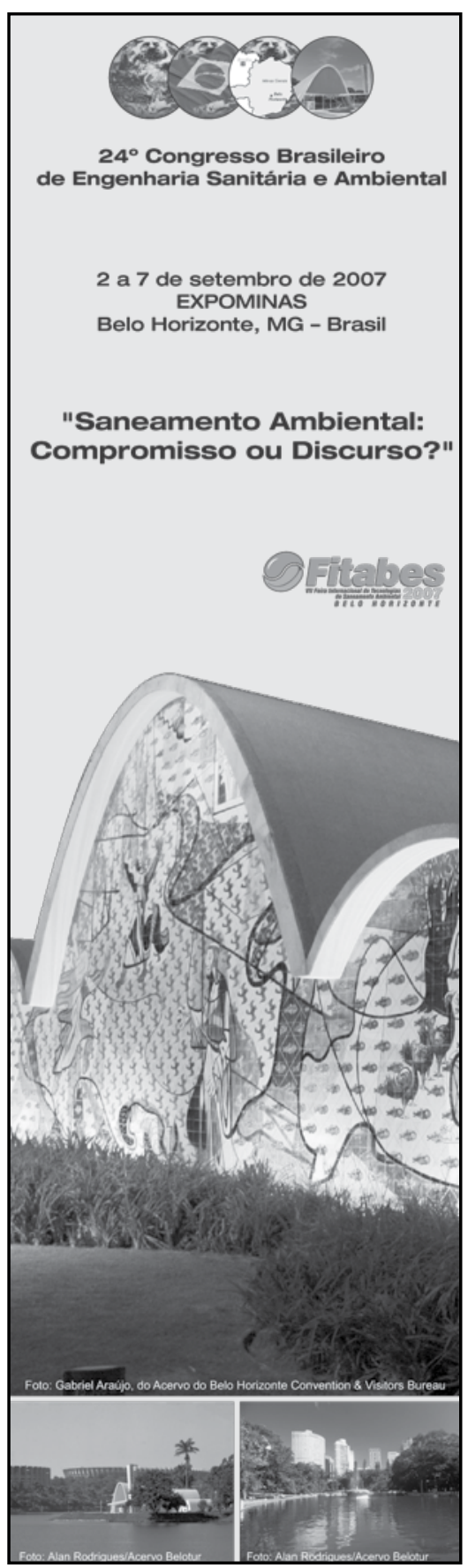

